\title{
The impact of corporate social responsibility on customer loyalty in the Qatari telecommunication sector
}

\author{
Ghaith M. Al-Abdallah \\ Faculty of Business \\ Applied Science Private University, Jordan \\ Ragy S. Ahmed \\ University of Liverpool, UK
}

\author{
Key words \\ Corporate Social Responsibility (CSR), Customer Loyalty (CL), Telecommunication Industry, Qatar.
}

\begin{abstract}
This study aims at examining the impact of Corporate Social Responsibility (CSR) on Customer Loyalty (CL) within the Telecommunication sector in the State of Qatar, the market in Qatar consists of two telecommunication providers; Ooredoo Qatar and Vodafone Qatar. Moreover, the study examines whether selected demographics (gender, age, income level and educational level) play any role in moderating the potential relation between CSR and CL. In order to accomplish this, the study utilized a descriptive analytical methodology and a quantitative research approach utilizing survey strategy. Using personally submitted questionnaires, 476 filtered and screened questionnaires were analyzed using SPSS software. The study revealed that customers perceived CSR activities as an essential element for them and for the operating organizations as well, moreover their awareness of such activities was salient through their responses to the questionnaire in place, and as a result, CSR activities were found to have a positive direct significant impact on CL. As for the suggested demographics, gender, age, and educational level didn't play any significant effective role in moderating the impact of CSR on CL. On the other hand, the Income Level slightly enhanced the original relationship between CSR and CL, as the higher the income level, the more CSR activities impact $C L$. Based on the results of the study, the researchers recommend that telecommunication providers should continue conducting CSR activities and focus more on ethical, economic, and environmental dimensions of CSR. Providers should also work on communicating their CSR activities to the public and customers to increase customer loyalty and maintain their market share. Recommendations for future research based on the results are also provided.
\end{abstract}

Corresponding author: Ghaith M. Al Abdallah

Email address for corresponding author: ghaith.abdallah@yahoo.com

First submission received: $5^{\text {th }}$ November 2017

Revised submission received: $18^{\text {th }}$ March 2018

Accepted: $16^{\text {th }}$ April 2018

\subsection{Introduction}

In a world where customers are becoming the core of attention for all organizations, their demands and wants are unavoidable for various reasons, and from an organizational point of view, the long-term strategic success lies down in listening and appealing to such desires, needs and wants. One of the major customers' concerns today is the social responsibility, or in other words, how organizations can be a positive member of the society, giving back to it, and operate according to the expectations set by individuals within that society. While it has been argued that an organizational response to such demands can grant great benefits and most importantly the loyalty of those customers (Martínez \& Del Bosque, 2013; Chomvilailuk \& Butcher, 2014) other opinions claim that such result is not really guaranteed (Afifah \& Asnan, 2015).

In one of the most dynamic sectors of the state of Qatar, both providers; Ooredoo and Vodafone are directing some considerable efforts and attention towards various types of Corporate Social Responsibility (CSR) activities, for instance; youth empowerment, education, philanthropic donations, reach out to un-deserved communities, health, women's empowerment, and infrastructure and 
innovation (Ooredoo, 2016; Vodafone, 2016). On the other hand, Customer Loyalty (CL) is perceived as an essential element and pillar for any business to survive and acquire long-term sustainability (Kotler \& Armstrong, 2008; Lewis \& Soureli, 2006; Lii et al., 2013, Cited in Shin \& Thai, 2015). Considering the wide diversity within the population of Qatar, with nationalities from all around the world (BQ-Magazine, 2014), this study intends to examine the relationship between CSR and CL within the Telecommunication sector in the state of Qatar, and to reveal whether CSR efforts are yielding the required impact on the consumers' behavior, represented in this study with CL.

\subsection{Research Background}

\subsection{Corporate Social Responsibility (CSR)}

Although CSR can be seen as an attribute of the modern era, in fact this concept is definitely not recent (Isaksson, Kiessling \& Harvey, 2014). Actually, the term Social Responsibility can be traced back to the 50's where Carroll (1999) argued that companies should give back to society, laying down the foundations of modern CSR concept. Even prior to the 50's there were certain publications that alluded CSR, for instance; Chester Barnard's (1938) The Functions of the Executive, J. M. Clark's (1939) Social Control of Business, and Theodore Kreps' (1940) Measurement of the Social Performance of Business.

According to IPSOS (2013), most surveyed consumers (77\% of them) consider it an obligation for organizations to operate in a manner that enhances the society's well-being. Not to mention the internal pressure presented by the employees themselves, as $60 \%$ demanded the same as well (Franklin, 2008). The aforementioned has significantly drawn more attention to CSR and dragged such concept into the spotlight.

CSR definition has been through different stages and names, for instance; corporate responsibility, corporate citizenship, and corporate social responsiveness (Wartick \& Cochran 1985, Carroll, 1999, Matten \& Crane, 2005). Carroll (1979) defined CSR (or what he called Corporate Social Performance) as the concept that covers the business obligations towards society which incorporates four elements; economic, legal, ethical and discretionary categories of business performance, prior to that, Davis (1960) conceptualized CSR as the organizational non-profit activities. More recent definition of CSR provided by Mohr, Webb \& Harris (2001) as "the company's commitment to minimizing or eliminating any harmful effects and maximizing its long-run beneficial impact on society". Stanisavljević (2017) considered CSR as the commitment to improve well-being through discretionary business practices and contributions of corporate resources. That being said, CSR can be defined in various ways depending on the perspective from which CSR is observed or examined, for instance, marketers highlight CSR in the shade of; causerelated marketing (Barone, Miyazaki, \& Taylor, 2000) social sponsorship (Simmons \& Becker-Olsen, 2006) environmental marketing (Crouch, 2006) communication with customers and their response to CSR (Caruana \& Crane, 2008) brand image and reputation (Berens, Riel, \& Bruggen, 2005).

CSR has been recognized as: a powerful tool that can distinguish organizations (Astaryan \& Asamoah, 2014), a tool that targets achieving economic, societal and environmental balance (Ali et al., 2010), a criterion for ranking and evaluating companies (Porter \& Kramer, 2006), and a line of defense for organizations against the different attacks and criticisms it may face. Along with the previous functionalities, CSR can be used as a marketing tool to compete and gain unique market position (Gallardo-Vázquez \& Sanchez-Hernandez, 2014). CSR can yield more investments (Smith, 2005, cited in Carroll \& Shabana, 2010), enhance corporate sales (Barone, Miyazaki, \& Taylor, 2000), improve corporate/brand image and reputation (Singh, Sanchez \&Del Bosque, 2008; Marin, Ruiz, \& Rubio, 2009) and attract more customers through influencing the way they perceive the company (Berens, Riel, \& Bruggen, 2005).

\subsection{Customer Loyalty (CL)}

It is prominent how different markets and industries are dynamically changing from focusing on products (Product-oriented) into focusing on consumers and creating long-term relationships with them (Customer-oriented). Nowadays, organizations are trying to achieve high level of customer satisfaction which is an essential prerequisite of CL (Kaur \& Soch, 2012; Pérez \& Del Bosque, 2015; Shafei \& Tabaa, 2016). CL can be achieved by knowing and meeting customers' needs and wants (Talpau \& Boscor, 2011; Lemon \& Verhoef, 2016). It is critical for organizations not only to attract more customers, but to maintain 
and keep the existing ones, commonly referred to as CL. Accordingly, CL has been highlighted as a crucial organizational target (Ganiyu, Uche \& Elizabeth, 2012), and an important area for continuous improvement (Aydin, Özer \& Arasil, 2005; Homburg, Jozi \& Kuehnl, 2015, cited in Lemon \& Verhoef, 2016; Shafei \& Tabaa, 2016) through which organizations can succeed in establishing profitable and longterm relations with their customers (Kim \& Kim, 2016).

$\mathrm{CL}$ is a polemic concept, looking at such concept from a holistic point of view, CL can be regarded as a consequence of all the experiences that a customer has with a product provider (Mascarenhas, Kesavan, \& Bernacchi, 2006). Maheshwari, Lodorfos, and Jacobsen (2014) defined CL as a customer's unconditional commitment to the company and his or her strong relationship with the brand, which is not likely to be affected under normal circumstances. Uncles, Dowling, and Hammond (2003) defined CL as a feature of people rather than something inherent in brands. Moreover, they have recognized CL to be one of the three common concepts of attitudes and behaviors, circumstances and purchase situations. The behavioral loyalty focuses on the customers' tendency of repeatedly conducting a purchase for a particular brand, while the attitudinal loyalty indicates that on top of committing to buy the same brand, customers have to positively perceive the brand which can be reflected by the customers' recommendations to others which are known as the word of mouth (Kaur \& Soch, 2012). Word of mouth has been identified as an important antecedent of CL, as according to Pizzutti and Fernandes (2010), there are two leading indicators that can interpret and clarify the level of CL to a certain organization, those are; consumers' intentions to repeatedly conduct a purchase of the same product, and the recommendation of the goods and services to others (aka word of mouth).

It is worth mentioning that within the academic literature authors and researchers heavily support the behavioral conceptualization of CL over other concepts, and they actually refer to it as the most realistic indicator and measurement of CL (Uncles, Dowling, \& Hammond, 2003). Researchers actually consider the behavioral loyalty to be a spurious or false loyalty, as the true loyalty shouldn't be entirely dependent on the purchasing behavior, instead along with this behavior; researchers argue that there should be a commitment towards the brand itself (Caceres \& Paparoidamis, 2014).

$\mathrm{CL}$ is indeed a critical component and salient indicator for any business persistent success (Aksoy, 2013), CL has various benefits to organizations, for instance, lower marketing costs, as loyal base of customers require less marketing campaigns, and hence higher revenues and profit (Mulki \& Jaramillo, 2011; Rafiq, Fulford \& Lu, 2013). In addition, acquiring new customers is not an easy task and may require what is known as offensive marketing which normally antagonizes the competitors and escalates commercial war. It is true that CL can help gaining new customers through word of mouth (as discussed above) but CL by definition means maintaining relationships with the existing customers, which is seen to be five times easier than putting the effort and cost of acquiring new customers (Gee, Coates, \& Nicholson, 2008), not mentioning the significant increment in the organization's market share with customer's willingness to remain with the brand even if the prices are higher than the competitors' (Aaker, 1996; Dick \& Basu, 1994; Nyadzayo \& Khajehzadeh, 2016).

\subsection{CSR and CL}

Many authors tried to explore the relationship between CSR practices and customer loyalty within different industries, however as the telecommunication sector is part of the service industry, below are some of the previous studies illustrating the attempts to study the relationship between CSR and CL through different types of services.

Rashid, Khalid, and Rahman (2015) examined whether CL is affected by three elements of environmental CSR, those are; philanthropy, community services, and society well-being. The study findings showed a positive relationship between each of community services, customer well-being and CL. The study also revealed that e-CSR philanthropy didn't show much influence on CL. Shin and Thai (2015) tested how the way customers perceived the CSR exercises (as a marketing tool), precisely the ethical and environmental ones impacted different elements including CL in the shipping industry in South Korea. The findings indicated that the higher the positive impact on customer satisfaction, the higher the relationship maintenance and customer's loyalty in order.

Moisescu (2015b) analyzed the CSR and CL relation based on the socio-cultural and economic dimensions of the Romanian telecommunication market, and it was found that CSR didn't play a 
significant role in impacting customer loyalty. Nevertheless, the study revealed that there is a need for full and transparent disclosure of CSR policies and activities, adopting more customer-centric approach, where customers are the center of attention, ensuring the fairness and adequacy of prices, and improving quality. Xu (2014) examined the relationship between CSR and CL in the fast food industry in China, precisely within the customers of McDonald's, by measuring five important aspects; consumer's dine-out behavior, expectations of CSR, perception of CSR, loyalty to and satisfaction of McDonald's customers and the demographics of the respondents. Xu found that the fast food diners in China emphasized on two particular activities of CSR, which are the human well-being and providing safe healthy/safe food, while other CSR activities were less important to customers.

Chomvilailuk and Butcher (2014) carried out an insightful study in the banking industry, to measure to which extent do both; service quality and CSR impact CL. The study treated and addressed customer's loyalty from a wider perspective, they referred to it as the loyalty outcomes that included; purchase intentions, affective commitment, and word of mouth. CSR was found to have a significant impact on both; word of mouth and purchasing intentions, while the influence on the affective commitment was relatively small compared to the service quality.

Martínez, and Del Bosque (2013) tested whether CL of hotels clients are impacted by CSR activities of hotels in Spain and within the hospitality sector, the study highlighted customer trust, customer satisfaction, and identification as mediating variables, and the results signified that CSR does strongly relate to each of the mediating variables mentioned previously, which in return enhances and improves CL.

Chen, Chang, and Lin (2012), investigated customers' loyalty in relation to how they observed CSR in Taiwan's airlines market, the study found that CSR can firmly enhance CL upon the control of relationship quality and that CSR within the airline industry, known as Airline Social Responsibility (ASR) influences both behavioral and attitudinal loyalty. Salmones, Perez and Del Bosque (2009) examined the Spanish financial sector by shedding the light on ethical and philanthropic practices of CSR, numerous dimensions were tested such as; relationship satisfaction, trust, identification with the firm, business performance, relational outcomes and loyalty, the results showed positive indirect relationship between CSR and CL through three critical dimensions; satisfaction, trust, and identification with the organization.

Salmones, Crespo, and Del Bosque (2005) focused on the mobile phones in Spain, where CSR was divided into three main categories; economic, ethical and philanthropic. Impact on customer loyalty was measured through each of the previous elements, and it has been noticed that each of them, except the economic dimension, positively influences the overall evaluation of the service and accordingly CL. CSR has different impact on CL ranging from very strong effect to no effect at all based on the dimensions tested and the market itself. Accordingly, it is hard to determine how CSR would impact CL in the telecommunication sector in Qatar.

\subsection{Role of Demographics}

Different demographics play an essential role in shaping consumers behavior and attitude. Having the customer loyalty as an aspect of such behavior, different researchers have tested such demographics influence. The majority examined demographics like; age, income, education and gender, to understand the impact of those variables on the original relationship between independents and dependents variables (Thomaidou \& Bellou, 2012; Astaryan \& Asamoah, 2014; Moisescu, 2015a; Kim \& Kim, 2016). Hence, this study considered the same demographics, namely; gender, age, income level and education level.

\subsection{Research Questions and Hypotheses}

The problem of this research can be formulated through the following questions:

Q.1 What is the effect of Corporate Social Responsibility (CSR) on Customer Loyalty (CL) in the Telecommunication sector of Qatar?

Q.2 If any, what is the moderating effect of selected demographics (age, income, education, and gender) on the relationship between Corporate Social Responsibility (CSR) and Customer Loyalty (CL)? In order to examine the above questions in quantitative approach, the following hypotheses were drafted 
Ha1: There is a significant positive direct impact of Corporate Social Responsibility (CSR) on Customer Loyalty (CL) in the Qatari Telecommunication sector at $a \leq 0.05$.

Ha2: Selected demographics (gender, age, income, and educational level) have a significant moderation effect on the original relationship between Corporate Social Responsibility (CSR) and Customer Loyalty $(\mathrm{CL})$ in the Qatari Telecommunication sector at $\mathrm{a} \leq 0.05$.

Ha2.1: Gender has a significant moderation effect on the original relationship between Corporate Social Responsibility (CSR) and Customer Loyalty (CL) in the Qatari Telecommunication sector at $a \leq 0.05$.

Ha2.2: Age has a significant moderation effect on the original relationship between Corporate Social Responsibility (CSR) and Customer Loyalty (CL) in the Qatari Telecommunication sector at $a \leq 0.05$.

Ha2.3: Income has a significant moderation effect on the original relationship between Corporate Social Responsibility (CSR) and Customer Loyalty (CL) in the Qatari Telecommunication Sector at $a \leq 0.05$.

Ha2.4 Educational level has a significant moderation effect on the original relationship between Corporate Social Responsibility (CSR) and Customer Loyalty (CL) in the Qatari Telecommunication sector at a $\leq 0.05$.

\subsection{Research Methodology}

Considering the nature of this study and the questions being addressed, this study has utilized a quantitative methodology, furthermore the research is following a descriptive methodology that is respectively following an analytical approach. In order to describe "What is" the nature of the relation between the variables (CSR \& CL) within the conditions of the Qatari market, and what are the customers' perception/response and attitude towards CSR practices of the telecommunication providers. The study utilized survey strategy; a questionnaire is used to collect the primary data as discussed below.

\subsection{Research Instrument}

The instrument used to collect the primary data of this study was the questionnaire. Five-points Likert scale ranging from "Strongly Disagree" to "Strongly Agree" with "I don't know" as a sixth option to minimize random and blank answers was developed based on the previous similar studies in order to measure certain aspects that were found to be critical for revealing the nature of the relationship between CSR and CL. The questionnaire was divided into three main parts, the first part is the cover letter as an introduction and an invitation for participants to undertake it, ethical aspects were covered to inform the participants about the student's identity, nature of the research and its goal, the full privacy and confidentiality of participants', The second part collected data on the research variables and consisted of 33 statements distributed between five directions as follow: importance of CSR (CSRIMP; 4 statements), awareness of CSR activities (CSR; 19 statements), customers' loyalty and attitudes towards their telecommunication provider (CL; 10 statements). Finally, the third part collected the demographics; characteristics of the respondents (4 statements), indicated the telecommunication provider that the respondent uses (1 statement) and the best communication channel through which participants recognize CSR activities (1 statement).

The research instrument was assessed through a pilot study in which copies of the questionnaires were send to a panel of expertise for final evaluation and upon their notes the final questionnaire was distributed to few random customers and friends. 43 copies were collected and tested for validity and reliability.

\subsubsection{Validity}

According to Heale and Twycross (2015) ensuring the research validity incorporates insuring validity on various levels, primarily, content validity, construct validity and face validity. The content validity mainly concerns with the ability of the measurement tool to rightly measure the targeted variable. While construct validity is the extent to which a test measures the concept or construct that it is intended to measure. Face validity is an estimate of whether a test appears to measure what it supposed to be measuring. All three validity testes were established as follow.

Both content validity and face validity were established based on the fact that the questionnaire was formed based on previous similar studies that measured the same variables, the feedback received from the panel of experts, and the 43 pilot study respondents. The language, clarity of statements and time needed to fill the questionnaire were also assessed during the pilot study. 
Construct validity was established using Person Correlation Coefficients; the results are presented in table 1 below.

\begin{tabular}{|c|c|c|c|c|c|}
\hline \multicolumn{4}{|l|}{ CSR } & \multicolumn{2}{|l|}{$\mathrm{CL}$} \\
\hline Item No. & $\mathrm{R}$ & Item No. & $\mathrm{R}$ & Item No. & $\mathrm{R}$ \\
\hline 1 & 0.526 & 11 & 0.750 & 1 & 0.738 \\
\hline 2 & 0.639 & 12 & 0.729 & 2 & 0.728 \\
\hline 3 & 0.650 & 13 & 0.689 & 3 & 0.79 \\
\hline 4 & 0.664 & 14 & 0.675 & 4 & 0.741 \\
\hline 5 & 0.733 & 15 & 0.722 & 5 & 0.796 \\
\hline 6 & 0.698 & 16 & 0.631 & 6 & 0.787 \\
\hline 7 & 0.652 & 17 & 0.730 & 7 & 0.715 \\
\hline 8 & 0.687 & 18 & 0.611 & 8 & 0.717 \\
\hline 9 & 0.629 & 19 & 0.524 & 9 & 0.670 \\
\hline 10 & 0.686 & & & 10 & 0.736 \\
\hline
\end{tabular}

Table (1) Construct Validity of Research Instrument

Table (1) provide the construct validity for the items of CSR and the items of CL, it indicates the Person correlation values calculated between each item and the total of the CSR, and the correlation values calculated between each item of CL and the total of CL. This kind of correlation expresses the construct validity. The maximum value of correlation is known to be (1), accordingly at least $50 \%$ of this value will be considered as a good correlation value to express the relation between each item and the total domain it belongs to (i.e. 0.50 or higher). Inspecting the provided values in the above table, it is clear that all values are $>0.50$ suggesting good and acceptable construct validity.

\subsubsection{Reliability}

The Cronbach alpha test was implemented to establish the reliability of the research instrument; the results are presented in table 2 below.

\begin{tabular}{|l|l|l|l|}
\hline \multicolumn{2}{|l|}{ Variable } & No. of Items & Reliability \\
\hline- & Importance of the CSR & 4 & 0.798 \\
\hline IV & CSR & 19 & 0.929 \\
\hline DV & CL & 10 & 0.903 \\
\hline & Questionnaire (IV and DV) & 29 & 0.944 \\
\hline
\end{tabular}

Table (2) Reliability Analysis

Table (2) indicates the results of Cronbach alpha analysis to measure reliability for the Items of: Importance of the CSR, CSR and the Items of CL. The values obtained were (0.798) for the Importance of the CSR, (0.929) for the items of CSR and (0.903) for CL. The value for the whole questionnaire is (0.944). The reliability values reflect a satisfactory reliability level (knowing that the maximum value that could be reached is 1.00) any value above 0.7 is considered a good value (Heale \& Twycross, 2015). Accordingly, a conclusion that the research instrument is reliable can be concluded.

\subsection{Research Population and Sample}

The research's population is basically all the mobile phone users in Qatar. Based on the annual reports of both Ooredoo and Vodafone; customers who are actually utilizing the mobile services of both providers are ranging between 1.548 million (Vodafone, 2016), to 1.76 million (Ooredoo, 2016), the total number of mobile phone users in Qatar is approximately 2.4 million which represent the research population that shall be examined. As discussed before, those 2.4 million are very diverse and from over 50 different nationalities and backgrounds, around 50\% of them are Asians (BQ-Magazine, 2014) and they all represent different income levels, educational levels, age and gender.

The study used probability sampling technique to come up with a representative sample, precisely, a stratified random sample was utilized to address the variation in the market share between both telecommunication providers in Qatar. Ooredoo Qatar acquires almost $68 \%$ of the market share, while Vodafone Qatar acquires the remaining; 32\%, hence the sample was constructed taking into consideration these percentages. 
According to Singh and Musuku (2014), the sample size for any given population that exceeds 100,000 members for a precision level of $5 \%$ and a confidence level of $95 \%$ should be above 400 . Therefore, the researchers distributed and send out 500 questionnaires proportionally. The distribution followed two methods; personally, submitted questionnaires. 480 questionnaires were retrieved with a response rate of $96 \%$. After the initial screening process, 4 incomplete questionnaires were eliminated, leaving 476 filtered and screened questioners for the statistical amylases, out of which, 322 were customers of Ooredoo (approximately 68\%), and 154 were customers of Vodafone (approximately 32\%) reflecting the market share of each telecommunication provider in Qatar.

\subsection{Data Analysis}

\subsection{Demographics Description}

The study consisted of six demographics items (Telecommunication Provider, Gender, Age, Educational level, Income, and Communication Channel of CSR). Table (3) represents the demographic characteristics of the study sample.

\begin{tabular}{|c|c|c|c|}
\hline Variable & Category & Counts & $\%$ \\
\hline \multirow{3}{*}{$\begin{array}{ll}\text { Main } & \text { Telecom } \\
\text { Provider } & \end{array}$} & Ooredoo Qatar & 322 & 67.6 \\
\hline & Vodafone Qatar & 154 & 32.4 \\
\hline & Total & 476 & 100.0 \\
\hline \multirow{3}{*}{ Gender } & Male & 250 & 52.5 \\
\hline & Female & 226 & 47.5 \\
\hline & Total & 476 & 100.0 \\
\hline \multirow{7}{*}{ Age } & Less than 20 & 11 & 2.3 \\
\hline & 20- less than 28 & 118 & 24.8 \\
\hline & 28- less than 35 & 200 & 42.0 \\
\hline & 35- less than 45 & 105 & 22.1 \\
\hline & 45 -Less than 60 & 35 & 7.4 \\
\hline & 60 and more & 7 & 1.5 \\
\hline & Total & 476 & 100.0 \\
\hline \multirow{6}{*}{ Income } & Less than 1,200 & 44 & 9.2 \\
\hline & 1,201 - Less than 14,000 & 305 & 64.1 \\
\hline & 14,001 - Less than 17,144 & 63 & 13.2 \\
\hline & 17,145 - Less than 87,000 & 61 & 12.8 \\
\hline & 87,000 and above & 3 & .6 \\
\hline & Total & 476 & 100.0 \\
\hline \multirow{6}{*}{ Educational Level } & High school level or less & 29 & 6.1 \\
\hline & 2 years Diploma & 42 & 8.8 \\
\hline & Bachelor Degree & 318 & 66.8 \\
\hline & Master Degree & 80 & 16.8 \\
\hline & PHD Degree & 7 & 1.5 \\
\hline & Total & 476 & 100.0 \\
\hline \multirow{7}{*}{$\begin{array}{l}\text { Communication } \\
\text { Channel }\end{array}$} & Social Media (Facebook, Instagram, Twitter, You Tube, others) & 306 & 64.3 \\
\hline & News Paper & 44 & 9.2 \\
\hline & Radio & 10 & 2.1 \\
\hline & Website & 34 & 7.1 \\
\hline & TV & 15 & 3.2 \\
\hline & Others & 67 & 14.1 \\
\hline & Total & 476 & 100.0 \\
\hline
\end{tabular}

Table (3) Describing the Sample's Personal and Demographic Characteristics 


\subsection{Hypotheses Testing}

\subsubsection{Testing the First Main Hypothesis}

Simple linear regression using SPSS were utilized to test the first main hypothesis and analyze the impact of Corporate Social Responsibility (CSR) on Customer Loyalty (CL). The results are shown in table (4)

Ha1: There is a significant positive direct impact of Corporate Social Responsibility (CSR) on Customer Loyalty (CL) in the Qatari Telecommunication sector at $a \leq 0.05$.

\begin{tabular}{|l|l|l|l|l|l|l|l|}
\hline Independent variable & $\mathrm{r}$ & $\mathrm{r}^{2}$ & $\mathrm{f}$ & $\operatorname{Sig}(\mathrm{f})$ & $\beta$ & $\mathrm{t}$ & $\operatorname{Sig}(\mathrm{t})$ \\
\hline Corporate Social Responsibility (CSR) & 0.628 & 0.394 & 308.43 & 0.000 & 0.681 & 17.56 & 0.000 \\
\hline
\end{tabular}

Table (4) Simple Linear Regression of CSR on CL in the Qatari Telecommunication sector

As presented in table (4), there is a statistically significant relationship between the variables with a value of (0.926) for the relationship. The $f$ value (308.43) is significant because the related Sig value (also known as $\mathrm{p}$ value) is $(0.000)$, which is statistically significant $(<0.05)$. The beta coefficient reflects the impact value of the independent variable on the dependent variable. The value is $(0.681)$ and significantly contributes to the dependent variable as the probability of $t$ statistics is $(0.000)<0.05$. The $t$ statistics tests the linearity importance of the beta coefficient obtained for the independent variable. The value of R2 expresses the variation percentage in the dependent variable that can be accounted for (i.e. explained by) the independent variable, it is found to be (39.4) which indicate that $39.4 \%$ of the variance in the dependent variable is predictable by the independent variable. Moreover, $\mathrm{r}$ value indicates a moderately strong impact of CSR on CL since the value is above 0.6 (Washington, 2017). As a result, the first main hypothesis is accepted.

\subsubsection{Testing the Second Main Hypothesis}

The second main hypothesis is divided into four sub-hypotheses and was tested through these subhypotheses. Multiple linear regressions were performed, and the results are presented next.

4.2.2.1 Testing the First Sub Hypothesis

Ha2.1: Gender has a significant moderation effect on the original relationship between Corporate Social Responsibility (CSR) on Customer Loyalty (CL) in the Qatari Telecommunication Sector at a $\leq 0.05$.

To test this hypothesis multiple linear regressions was performed. The results are included in table (5) below.

\begin{tabular}{|c|c|c|c|c|c|c|c|}
\hline Independent variables & $\mathrm{R}$ & $\mathrm{R}^{2}$ & $\mathrm{~F}$ & $\operatorname{Sig}(\mathrm{f})$ & $\beta$ & $\mathrm{t}$ & $\operatorname{Sig}(t)$ \\
\hline CSR & \multirow{3}{*}{0.629} & \multirow{3}{*}{0.395} & \multirow{3}{*}{102.77} & \multirow{3}{*}{0.000} & 0.520 & 17.46 & 0.000 \\
\hline Gender & & & & & -0.025 & -0.84 & 0.399 \\
\hline Moderation effect & & & & & -0.003 & -0.11 & 0.910 \\
\hline
\end{tabular}

Table (5) Multiple Linear Regression for Testing the Moderation Effect of Gender on the Original Relationship between CSR and CL

The results provided show that the model consisting of CSR and gender is statistically significant as the probability of $f$ test $(0.000)$ is less than 0.05 . The impact value for CSR on CL is $(0.520)$ this value is statistically significant because the probability value $(0.000)$ related to $t$ test is $<0.05$. The effect of gender on CL is (- 0.025). The value of effect is not statistically significant as the probability of $t$ test $(0.399)$ is > 0.05. Comparing the value of R2 for the current model (moderation model) which is (0.395) with the value of R2 for the basic model that tests the effect of CSR on CL (in the first main hypothesis) which was (0.394), It is obvious that the two values are approximately the same and that only a negligible increase of (0.001) can be noticed. Accordingly, gender did not enhance the power of the model by increasing the value of R2 to explain more variance in the CL. Moreover, the Moderation effect in the model is not statistically significant as the probability value $(0.910)$ is $>0.05$ and the impact value is very small $(-0.003)$. Accordingly, a conclusion that gender did not moderate the original relationship between CSR and CL can be drawn and as a result, the hypothesis is rejected.

\subsubsection{Testing the Second Sub Hypothesis}

Ha2.2 Age has a significant moderation effect on the original relationship between Corporate Social Responsibility (CSR) on Customer Loyalty (CL) in the Qatari Telecommunication Sector at $a \leq 0.05$.

To test this hypothesis multiple linear regressions was performed. The results are included in table (6) 


\begin{tabular}{|c|c|c|c|c|c|c|c|}
\hline Independent variables & $\mathrm{R}$ & $\mathrm{R}^{2}$ & $\mathrm{~F}$ & $\operatorname{Sig}(f)$ & $\beta$ & $\mathrm{t}$ & $\operatorname{Sig}(\mathrm{t})$ \\
\hline CSR & \multirow{3}{*}{0.630} & \multirow{3}{*}{0.397} & \multirow{3}{*}{103.71} & \multirow{3}{*}{0.000} & 0.520 & 17.46 & 0.000 \\
\hline Age & & & & & -0.045 & -1.53 & 0.125 \\
\hline Moderation effect & & & & & 0.009 & 0.31 & 0.757 \\
\hline
\end{tabular}

Table (6) Multiple Linear Regression for Testing the Moderation Effect of Age on the Original Relationship between CSR and CL

The results provided show that the model consisting of the CSR and age is statistically significant as the probability of $f$ test $(0.000)$ is less than 0.05 . The impact value for CSR on CL is $(0.520)$, this value is statistically significant because the probability value $(0.000)$ related to $t$ test is $<0.05$. The effect of age on $\mathrm{CL}$ is (- 0.045). The value of effect is not statistically significant as the probability of $t$ test $(0.125)$ is $>0.05$. Comparing the value of R2 for the current model (moderation model) which is (0.397) with the value of R2 for the basic model that tests the effect of CSR on CL (which was 0.394), It is obvious that the R2 values are approximately the same and that only a negligible increase of $(0.003)$ can be noticed. Therefore, age did not enhance the power of the model by increasing the value of $\mathrm{R} 2$ to explain more variance in the CL. The Moderation effect in the model is not statistically significant as the probability value $(0.757)$ is $>0.05$, moreover the impact value is very small (0.009). Accordingly, a conclusion that age did not moderate the original relationship between CSR and CL can be drawn and as a result, the alternative hypothesis is rejected.

\subsubsection{Testing the Third Sub Hypothesis}

Ha2.3 Income has a significant moderation effect on the original relationship between Corporate Social Responsibility (CSR) on Customer Loyalty (CL) in the Qatari Telecommunication Sector at $a \leq 0.05$.

To test this hypothesis multiple linear regressions was performed. The results are included in table (7)

\begin{tabular}{|c|c|c|c|c|c|c|c|}
\hline Independent variables & $\mathrm{R}$ & $\mathrm{R}^{2}$ & $\mathrm{~F}$ & $\operatorname{Sig}(\mathrm{f})$ & $\beta$ & $\mathrm{t}$ & $\operatorname{Sig}(t)$ \\
\hline CSR & \multirow{3}{*}{0.644} & \multirow{3}{*}{0.415} & \multirow{3}{*}{111.60} & \multirow{3}{*}{0.000} & 0.520 & 17.46 & 0.000 \\
\hline Income & & & & & -0.099 & -3.35 & 0.001 \\
\hline Moderation effect & & & & & -0.065 & -2.19 & 0.029 \\
\hline
\end{tabular}

Table (7) Multiple Linear Regression for Testing the Moderation Effect of Income on the Original Relationship between CSR and CL

The results provided show that the model consisting of the CSR and income is statistically significant as the probability of $f$ test $(0.000)$ is less than 0.05 . The impact value for CSR on CL is $(0.520)$, this value is statistically significant because the probability value $(0.000)$ related to $t$ test is $<0.05$. The effect of income on CL is (-0.099). The value of effect is statistically significant as the probability of $t$ test $(0.001)$ is $<0.05$. Comparing the value of R2 for the current model (moderation model) which is $(0.415)$ with value of R2 for the basic model that tests the effect of CSR on CL which was (0.394), an increase of (0.021) equivalent to $5.3 \%$ of the original value can be noticed. Accordingly, income enhances the power of the model by slightly increasing the value of $\mathrm{R} 2$ to explain more variance in the CL.

The Moderation of effect in the model is statistically significant as the probability value $(0.029)$ is $<0.05$, however, the impact value is small (- 0.065). Accordingly, a conclusion that income moderates the original relationship between CSR and CL can be drawn and as a result, the alternative hypothesis is accepted.

4.2.2.4 Testing the Fourth Sub Hypothesis

Ha2.4 Educational level has a significant moderation effect on the original relationship between CSR and $\mathrm{CL}$ at $\mathrm{a} \leq 0.05$.

To test this hypothesis multiple linear regressions was performed. The results are included in table (8)

\begin{tabular}{|c|c|c|c|c|c|c|c|}
\hline Independent variables & $\mathrm{R}$ & $\mathrm{R}^{2}$ & $\mathrm{~F}$ & $\operatorname{Sig}(\mathrm{f})$ & $\beta$ & $\mathrm{t}$ & $\operatorname{Sig}(t)$ \\
\hline CSR & \multirow{3}{*}{0.643} & \multirow{3}{*}{0.414} & \multirow{3}{*}{111.13} & \multirow{3}{*}{0.000} & 0.520 & 17.46 & 0.000 \\
\hline Education & & & & & -0.111 & -3.79 & 0.000 \\
\hline Moderation effect & & & & & -0.032 & -1.22 & 0.221 \\
\hline
\end{tabular}

Table (8) Multiple Linear Regression for Testing the Moderation Effect of Educational Level on the Original Relationship between CSR and CL

The results provided that the model consisting of the CSR and educational level is statistically significant as the probability of $f$ test $(0.000)$ is less than 0.05 . The impact value for CSR on CL is $(0.520)$, this value is statistically significant because the probability value $(0.000)$ related to $t$ test is $<0.05$. The 
effect of educational level on CL is (- 0.111). The value of effect is statistically significant as the probability of $t$ test $(0.000)$ is $<0.05$. Comparing the value of $\mathrm{R} 2$ for the current model (moderation model) which is (0.414) with the value of R2 for the basic model that tests the effect of CSR on CL which was (0.394) an increase of $(0.020)$ which is equivalent to $5 \%$ can be noticed. Apparently, educational level enhances the power of the model to explain more variance in the CL by slightly increasing the value of R2. However, the Moderation of effect in the model at large is not statistically significant as the probability value (0.221) is $>0.05$, and the impact value is small (- 0.032). Accordingly, a conclusion that educational level did not moderate the original relationship between CSR and CL can be drawn and as a result, the alternative hypothesis is rejected.

\subsection{Results and Discussion}

Both elements of Corporate Social Responsibility and Customer Loyalty have attracted the attention of different researchers, hence various studies have been conducted to examine the nature of relationship these two elements may have in common, as explained earlier. The results of these previous studies varied between concluding a positive correlation or a negative one, thus it was critical to understanding the nature of this relationship in the Qatari Telecommunication sector, which is considered one of the fastest growing telecommunication markets in the region with a highly fast rate of growth (Oxford Business Group, 2017), which hasn't been explored before to the best of the researchers' knowledge.

The results showed that customers in the Qatari Telecommunication sector do pay attention and are aware of the CSR-related activities, more importantly they do believe that the existence of such activities and the organizations involvement in it is significantly important. Such results are good indicators of a progress in the customers' mentality and awareness in developing countries that is going through a relatively fast development and rapid growth on various levels.

The study found out that almost all different types of CSR activities conducted by the telecom providers are being noted and acknowledged by their customers, however the CSR activities that seemed to gain more interest and higher attention are those activities falling under the philanthropic, legal, and social umbrella/dimensions, other activities are related to the ethical, economic, and environmental dimensions are being noticed as well but not on the same level as the previously mentioned dimensions. Having the first three CSR dimensions being the most seen by customers can in fact indicate that a higher value is placed on these dimensions; the remaining CSR categories that acquire less attention need more efforts from both providers.

The study reported that customers of the Qatari Telecommunication sector tend to have high level of loyalty to their providers. Moreover, it has been acknowledged that customers have high tendency to recommend their telecommunication provider to others and positively talk about them, which is by definition a positive WOM. Also, the tendency of conducting a repurchase was relatively high and is considered as a sort of behavioral loyalty (Kaur \& Soch, 2012), Nevertheless, it is essential to highlight that price tolerance tendency is not as high as the rest of loyalty aspects, such results express that customers' loyalty might actually be negatively impacted in case the telecommunication providers raise the prices of their services.

The study pointed out that the way customers perceive CSR activities of their telecommunication providers have an impact on their loyalty, which aligns with previous studies that aimed at exploring the same (Chen, Chang, \& Lin, 2012; Martínez \& Del Bosque, 2013; Rashid, Khalid, \& Rahman, 2015). Other studies showed that the correlation is indirectly positive, through other mediating variables such as the whole evaluation of service, the word of mouth, the purchase intentions and the satisfaction level (Salmones, Perez, \& Del Bosque, 2009; Mandhachitara and Poolthong, 2011; Choi and La, 2013; Chomvilailuk \& Butcher, 2014; Shin \& Thai, 2015). The results of this study indeed contradict with other studies that found insignificant correlation between CSR and CL (Xu, 2014; Moisescu, 2015b). This might be due to cultural differences and lack of general awareness of CSR importance to society.

This study focused on exploring the role of certain demographics such as; Gender, Age, Level of Income, and Level of education in moderating the original relationship between CSR and CL. Although the study sample had very close male to female ratio (52.5\% males to $47.5 \%$ females) it was found that the gender element doesn't contribute or moderate the impact of CSR on CL. In addition, assessing the 
collected data about the age, it was found that the highest age category was customers who aged between 28 to less than 35 years old, forming around $42 \%$ of the total respondent. Nevertheless, all age categories were insignificant in terms of moderating the original impact of CSR on CL. In the income level aspect, it was found that respondents with median income $(1,201$ - Less than 14,000$)$ constructed $64.1 \%$ of the study's sample. Unlike previous demographics, customers with higher levels of income were found to be more sensitive to CSR activities in terms of their loyalty, in other words the higher the income is, the higher the loyalty to telecom providers involved in CSR is. This could be contributed to the fact that higher income is in a way associated with better quality of education, more exposure to developed cultures and sustainable lifestyle. Next and lastly, the study addressed the level of education; most of the respondents were bachelor's degree holders (66.8\% of the sample). By analyzing possible moderating effect of the educational level, it was revealed that even though the educational level is a critical demographic aspect, it didn't really moderate the relationship between CSR and CL indicating that the level of awareness is almost the same across the different educational level categories.

\subsection{Conclusions \& Recommendations}

By accomplishing this study goals and generating the statistical results; the study has in fact made contributions on two different levels. Firstly, the academic dimension, where concluding the positive impact of CSR on CL highlights the important role CSR represents in directing consumers' behavior, specifically the element of customer loyalty, which is an addition to all the previous literature examining CSR. Secondly, the study is an index to whether the companies' efforts in communicating their activities to the public are effective or not, which is a contribution on the professional level as it turns out that CSR activities impact consumers in the Telecommunication sector in Qatar. The results revealed that customers in the Qatari Telecommunication sector pay attention to and aware of the CSR-related activities, and they do believe that the existence of, and the organizations' involvement in such activities is significantly important for them and should be as well for organizations. Such result actually is an indicator of a progress in the customers' mentality and awareness in a developing country that is going through a relatively fast development/progress as well as a rapid growth on various levels.

Looking at the role of demographics, it was found that the gender element doesn't actually contribute or moderate the impact of CSR on CL, similarly age was found to be irrelevant in terms of influencing the impact of CSR on CL, however customers with higher levels of income were found to be more sensitive to CSR activities in terms of their loyalty, lastly it was revealed that even though the educational level is a critical demographic aspect, it didn't really moderate the relationship between CSR and CL. The CSR activities that seemed to gain more interest and higher attention are those activities falling under the philanthropic, legal, and social umbrella, other events related to the ethical, economic, and environmental aspects are being noticed as well but not on the same level as the previously mentioned categories. Accordingly, CSR categories that acquired less attention shall need more efforts from both providers in terms of educating customers and increasing their awareness.

In terms of loyalty, customers tend to have high level of loyalty to their providers, with high tendency to recommend their Telecommunication providers to others and positively talk about them, which is considered a positive WOM. In addition, the tendency of conducting a repurchase was relatively high and which is sort of behavioral loyalty that organizations normally seek (Kaur \& Soch, 2012) and an index to strong loyalty that organizations normally aspire (Oliver, 1997, Cited in Uncles, Dowling, \& Hammond, 2003).

In conclusion, the study has shown that CSR does impact CL, therefore both providers shall pay attention on continuing and improving their CSR practices, furthermore out of all the CSR statements that indicate the organizations' activities, the consumer related activities, products and services prices, and environmental activities are the ones gaining the least awareness and attention, this might require both telecommunication providers to do more effort in educating and increasing the customers' awareness about the importance of environmental causes and subsequently their activities in supporting, advocating and protecting such causes.

\subsection{Recommendations for Future Studies}

A critical aspect that future studies can incorporate within their research is the demographic element of ethnicity, this is due to the massive diversity of nationalities and ethnicities of Qatar that might 
actually give more insightful information about such role in moderating the relationship between CSR and $\mathrm{CL}$, taking into consideration that different cultures do construct and contribute to individuals' behaviors, perceptions and attitudes (Muwazir \& Abdul Hadi, 2013).

It would be recommended for future research to inspect and explore the same variables within different areas, sectors and industries, this can provide a holistic view of the perception and attitudes toward CSR in Qatar and can be utilized for cross-sectional comparisons and development purposes. Also, future research may expand on a geographical basis to examine the same variables but within different markets in other countries of the Gulf region to compare the results.

\subsection{Limitations}

Financial and time limitations prevented the researchers from expanding the horizon of the study to include other intervening variables and larger cluster sample instead of stratified one. CSR and CL dimensions could be viewed from different aspects and perspectives, other than the one used in this study.

\section{Acknowledgements}

The first author is grateful to the Applied Science Private University, Amman, Jordan, for the financial support granted to this research project (DRGS-2017-20148-60).

\section{References}

Aaker, D. A. (1996) ‘Measuring brand equity across products and markets', California Management Rev. 38 (Spring), pp. 102-120.

Afifah, N. and Asnan, A. (2015) 'The impact of corporate social responsibility, service experience and Intercultural competence on customer company identification, customer satisfaction and customer loyalty (case study: PDAM TirtaKhatulistiwa Pontianak west Kalimantan)', Procedia - Social and Behavioral Sciences, 211, pp. 277284.

Aksoy, L. (2013) 'How do you measure what you can't define? The current state of loyalty measurement and management', Journal of Service Management, 24(4), p356-381. Available at: http://www.emeraldinsight.com.liverpool.idm.oclc.org/doi/pdfplus/10.1108/JOSM-01-2013-0018 (Accessed: 19 September 2016).

Ali, I., Rehman, KU., Yilmaz, AK., Nazir, S. and Ali JF. (2010) 'Effects of corporate social responsibility on consumer retention in cellular industry of Pakistan', African Journal of business Management, 4(4), pp: 475-485. Available from http://www.ciitlahore.edu.pk/papers/abstracts/146-8589069439950694923.pdf (Accessed: 18 December 2016).

Astaryan, R. and SelaseAsamoah, E. (2014) 'Perceived Corporate Social Responsibility (CSR) Activities and the Antecedents of Customer Loyalty in the Airline Industry', Scientific Papers of the University of Pardubice. Series D, Faculty of Economics \& Administration, 21(32), pp. 5-17. Available at:

http:/ / content.ebscohost.com/ContentServer.asp?T=P\&P=AN\&K=100431930\&S=R\&D=a9h\&EbscoContent $=\mathrm{d}$ GJyMMvl7ESeqLQ40dvuOLCmr06ep7BSrqa4TLKWxWXS\&ContentCustomer=dGJyMOzprkmvqLJPuePfgeyx 43zx (Accessed: 19 September 2016).

Aydin, S., Özer, G. and Arasil, Ö. (2005) 'Customer loyalty and the effect of switching costs as a moderator variable'. Marketing Intelligence \& Planning, 23(1), pp.89-103. Available at:

http://www.emeraldinsight.com.liverpool.idm.oclc.org/doi/pdfplus/10.1108/02634500510577492 (Accessed: 13 April 2017).

Barnard, C. (1938). The Functions of the Executive. Cambridge: Harvard University Press.

Barone, M.J., Miyazaki, A.D. and Taylor, K.A. (2000) 'The influence of cause-related marketing on consumer choice: Does One good turn deserve another?', Journal of the Academy of Marketing Science, 28(2), pp. 248-262. Available at:

http:/ / content.ebscohost.com/ContentServer.asp?T=P\&P=AN\&K=2967026\&S=R\&D=bth\&EbscoContent=dGJ yMMvl7ESeprM4wtvhOLCmr06eprNSrqe4SLWWxWXS\&ContentCustomer=dGJyMOzprkmvqLJPuePfgeyx4 3zx (Accessed: 5 December 2016).

Berens, G., Riel, C.B.M. van and Bruggen, G.H. van (2005) ‘Corporate associations and consumer product responses: The moderating role of corporate brand dominance', Journal of Marketing, 69(3), pp. 35-48. Available at: http:/ / content.ebscohost.com/ContentServer.asp?T=P\&P=AN\&K=17533922\&S=R\&D=bth\&EbscoContent=dG JyMNXb4kSep7c4zdnyOLCmr06eprNSsq24TLKWxWXS\&ContentCustomer=dGJyMOzprkmvqLJPuePfgeyx43 zx (Accessed: 19 October 2016).

BQ-Magazine (2014) ‘Population of Qatarby Nationality'. Available at: http://www.bq-magazine.com/economy/2013/12/population-qatar-nationality (Accessed: 10October, 2016). 
Caceres, R.C., and Paparoidamis, N.G. (2014) 'Service quality, relationship satisfaction, trust, commitment and business-to-business loyalty', European Journal of Marketing, Vol. 41, Issue 7/8, pp. 836-867.Available at: http:/ / www.emeraldinsight.com.liverpool.idm.oclc.org/doi/pdfplus/10.1108/03090560710752429 (Accessed: 30 April 2017).

Carroll, A.B. (1979) 'A Three-Dimensional conceptual model of corporate performance', The Academy of Management Review, 4(4), pp. 497-505. Available at:

http:/ / content.ebscohost.com/ContentServer.asp?T=P\&P=AN\&K=4498296\&S=R\&D=bth\&EbscoContent=dGJ yMMvl7ESeprM4wtvhOLCmr06eprJSr624S7KWxWXS\&ContentCustomer=dGJyMOzprkmvqLJPuePfgeyx43z x (Accessed: 5 December 2016).

Carroll, A.B. (1999) 'Corporate Social Responsibility', Business \& Society, 38(3), p268-295. Available at: http:/ / bas.sagepub.com.liverpool.idm.oclc.org/content/38/3/268.full.pdf (Accesed: 1 December 2016).

Carroll, A.B. and Shabana, K.M. (2010) 'The business case for corporate social responsibility: A review of concepts, research and practice', International Journal of Management Reviews, 12(1), pp. 85-105. Available at: http:/ / content.ebscohost.com/ContentServer.asp? $\mathrm{T}=\mathrm{P} \& \mathrm{P}=\mathrm{AN} \& \mathrm{~K}=47582555 \& \mathrm{~S}=\mathrm{R} \& \mathrm{D}=\mathrm{bth} \&$ EbscoContent $=\mathrm{dG}$ JyMNLr40SeqK44wtvhOLCmr06eprJSsKi4S7aWxWXS\&ContentCustomer=dGJyMOzprkmvqLJPuePfgeyx43z x (Accessed: 20 December 2016).

Caruana, R. and Crane, A. (2008) 'Constructing consumer responsibility: Exploring the role of corporate communications', Organization Studies, 29(12), pp. 1495-1519. Available at:

http://oss.sagepub.com.liverpool.idm.oclc.org/content/29/12/1495.full.pdf (Accessed: 5 December 2016).

Chapple, W. and Moon, J. (2005) 'Corporate social responsibility (CSR) in Asia: A Seven-Country study of CSR web site reporting', Business \& Society, 44(4), pp. 415-441. Available at:

http:// bas.sagepub.com.liverpool.idm.oclc.org/content/44/4/415.full.pdf (Accessed: 19 September).

Chen, F.-Y., Chang, Y.-H. and Lin, Y.-H. (2012) 'Customer perceptions of airline social responsibility and its effect on loyalty', Journal of Air Transport Management, 20, pp. 49-51. Available at:

http:/ / ehis.ebscohost.com.liverpool.idm.oclc.org/eds/SmartLink/OpenEjsSmartLink?sid=379e3205-c7aa-

41da-aec6-6a1f064089cf@sessionmgr103\&vid=1 (Accessed: 19 September 2016).

Choi, B. and La, S. (2013) 'The impact of corporate social responsibility (CSR) and customer trust on the restoration of loyalty after service failure and recovery', Journal of Services Marketing, 27(3), pp. 223-233. Available at: http://www.emeraldinsight.com.liverpool.idm.oclc.org/doi/pdfplus/10.1108/08876041311330717 (Accessed: 18 September).

Chomvilailuk, R. and Butcher, K. (2014) 'Effects of quality and corporate social responsibility on loyalty', The Service Industries Journal, 34(11), pp. 938-954. Available at:

http:/ / content.ebscohost.com/ContentServer.asp?T=P\&P=AN\&K=97066700\&S=R\&D=bth\&EbscoContent=dG JyMMv17ESeqLQ40dvuOLCmr06ep69Ssq24S7KWxWXS\&ContentCustomer=dGJyMOzprkmvqLJPuePfgeyx43 zx (Accessed: 18 September 2016).

Clark J. M. (1939), Social Control of Business, New York, McGraw Hill.

Crouch, C. (2006) 'Modelling the firm in its market and organizational environment: Methodologies for studying corporate social responsibility', Organization Studies, 27(10), pp. 1533-1551. Available at: http:/ / oss.sagepub.com.liverpool.idm.oclc.org/content/27/10/1533.full.pdf (Accessed: December 2010)

Davis, K. (1960) 'Can Business Afford to Ignore Social Responsibilities?', California Management Review, Vol. 2 Issue 3, p70-76. Available at:

http:/ / content.ebscohost.com/ContentServer.asp?T=P\&P=AN\&K=6539178\&S=R\&D=bth\&EbscoContent=dGJ yMNHr7ESeqa44v\%2BbwOLCmr0\%2BeprFSsa24SrSWxWXS\&ContentCustomer=dGJyMOzprkmvqLJPuePfge yx43zx (Accessed: 30 April 2017).

Del Mar Garcia de los Salmones, M., Perez, A. and Del Bosque, I.R. (2009) 'The social role of financial companies as a determinant of consumer behaviour', International Journal of Bank Marketing, 27(6), pp. 467-485. Available at: http:/ / www.emeraldinsight.com.liverpool.idm.oclc.org/doi/pdfplus/10.1108/02652320910988339 (Accessed: 26 September 2016).

Dick, A. and Basu, K., (1994) 'Customer loyalty: towards an integrated framework', Journal of the Academy of Marketing Science, 22 (2), pp.99-113.

Franklin (2008) 'Just good business: A special report on corporate social responsibility', The Economist. Available at: http://www.yooyahcloud.com/MOSSCOMMUNICATIONS/RQ93b/Just_good_business_ECONOMIST.pdf (Accessed: 19 December 2016).

Gallardo-Vázquez, D. and Sanchez-Hernandez, M.I. (2014) 'Measuring corporate social responsibility for competitive success at a regional level', Journal of Cleaner Production, 72, pp. 14-22. Available at: http://ehis.ebscohost.com.liverpool.idm.oclc.org/eds/SmartLink/OpenEjsSmartLink?sid=2aa171ce-688149c7-92b4-523a0fa8a51b@sessionmgr106\&vid=1 (Accessed: 19 September 2016). 
Ganiyu, R.A., Uche, I.I., and Elizabeth, A.O. (2012) 'Is Customer Satisfaction an Indicator of Customer Loyalty?', Australian Journal of Business and Management Research, Vol.2 No.07 pp:14-20. Available at: http:/ / www.ajbmr.com/articlepdf/aus-27-11i7n2a2.pdf (Accessed: 13 April 2017).

Gee, R., Coates, G. and Nicholson, M. (2008) 'Understanding and profitably managing customer loyalty', Marketing Intelligence \& Planning, 26(4), pp. 359-374. Available at:

http:/ / www.emeraldinsight.com.liverpool.idm.oclc.org/doi/pdfplus/10.1108/02634500810879278 (Accessed: 19 September 2016).

Heale, R. and Twycross, A. (2015) 'Validity and reliability in quantitative studies', Evidence Based Nursing, 18(3), pp.66-67. Available at:

http:/ /ebn.bmj.com.liverpool.idm.oclc.org/content/ebnurs/18/3/66.full.pdf (Accessed: 6 April 2017).

Ipsos (2013) Eight out of Ten Australians Rate Corporate Social Responsibility as Important. Available at: http://ipsos.com.au/wp-content/uploads/2013/06/Corporate-social-responsibility-media-release-FINAL. Pdf (Accessed: 20 November 2016).

Isaksson, L., Kiessling, T. and Harvey, M. (2014) 'Corporate social responsibility: Why bother?', Organizational Dynamics, 43(1), pp.64-72. Available at: http://ac.els-cdn.com.liverpool.idm.oclc.org/S0090261613000740/1s2.0-S0090261613000740-main.pdf?_tid=427fb40c-2d85-11e7-b53b-

00000aacb362\&acdnat=1493543783_a48e18e9adf80c4204bebad0771a7d14 (Accessed: 30 April 2017).

Kaur, H., and Soch, H. (2012) 'Validating Antecedents of Customer Loyalty for Indian Cell Phone Users', Vikalpa: The Journal for Decision Makers, 37(4), pp. 47-61. Available at:

http:/ / content.ebscohost.com/ContentServer.asp?T=P\&P=AN\&K=84616523\&S=R\&D=bth\&EbscoContent=dG JyMNLr40Sep7E4wtvhOLCmr06eprZSsqe4Ta6WxWXS\&ContentCustomer=dGJyMOzprkmvqLJPuePfgeyx43z x (Accessed: 13 December 2016).

Kreps, Theodore J. (1940) 'Measurement of the Social Peribrmance of Business', Monograph No. 7. Washington, DC: U.S. Government Printing Office.

Kim, S.-B. and Kim, D.-Y. (2016) 'The influence of corporate social responsibility, ability, reputation, and transparency on hotel customer loyalty in the U.S.: A gender-based approach', SpringerPlus, 5(1). Available at: http:/ /eds.b.ebscohost.com.liverpool.idm.oclc.org/eds/detail/detail?sid=bc67a87f-1d8d-45fb-8c3f 34d367c299de\%40sessionmgr106\&vid=0\&hid=111\&bdata=JnNpdGU9ZWRzLWxpdmUmc2NvcGU9c210ZQ\% 3d \%3d\#AN=edselc.2-52.0-84987875305\&db=edselc (Accessed: 19 October 2016).

Lemon, K.N. \&Verhoef, P.C. (2016) 'Understanding Customer Experience Throughout the Customer Journey', Journal of Marketing, Available at:

http:/ / content.ebscohost.com/ContentServer.asp?T=P\&P=AN\&K=119129834\&S=R\&D=bth\&EbscoContent=d GJyMNLr40Sep7E4wtvhOLCmr06eprVSsK64TK\%2BWxWXS\&ContentCustomer=dGJyMOzprkmvqLJPuePfg eyx43zx (Accessed: 13 December 2016).

Maheshwari, V., Lodorfos, G., \& Jacobsen, S. (2014) 'Determinants of brand loyalty: A study of the experiencecommitment-loyalty constructs', International Journal of Business Administration, 5(6), 13-23. Available at: http:/ / www.sciedu.ca/journal/index.php/ijba/article/download/5906/3533 (Accessed: 14 March 2018)

Mandhachitara, R. and Poolthong, Y. (2011) 'A model of customer loyalty and corporate social responsibility', Journal of Services Marketing, 25(2), pp. 122-133. Available at:

http://www.emeraldinsight.com.liverpool.idm.oclc.org/doi/pdfplus/10.1108/08876041111119840 (Accessed: 19 September 2016).

Marin, L., Ruiz, S. and Rubio, A. (2009) 'The role of identity Salience in the effects of corporate social responsibility on consumer behavior', Journal of Business Ethics, 84(1), pp. 65-78. Available at:

http:/ / content.ebscohost.com/ContentServer.asp?T=P\&P=AN\&K=35489117\&S=R\&D=bth\&EbscoContent=dG JyMNXb4kSep7c4zdnyOLCmr06eprNSsa\%2B4SLWWxWXS\&ContentCustomer=dGJyMOzprkmvqLJPuePfge yx43zx (Accessed: 19 October 2016).

Martínez, P. and Del Bosque, I.R. (2013) 'CSR and customer loyalty: The roles of trust, customer identification with the company and satisfaction', International Journal of Hospitality Management, 35, pp. 89-99. Available at: http:/ / ac.els-cdn.com.liverpool.idm.oclc.org/S0278431913000790/1-s2.0-S0278431913000790main.pdf?_tid=426535be-83fd-11e6-b6c700000aacb35d\&acdnat=1474903624_6ef43cd0888a497e92369b533e302cbf (Accessed: 26 September 2016).

Mascarenhas, O.A., Kesavan, R. and Bernacchi, M. (2006) 'Lasting customer loyalty: A total customer experience approach', Journal of Consumer Marketing, 23(7), pp. 397-405. Available at:

http://www.emeraldinsight.com.liverpool.idm.oclc.org/doi/pdfplus/10.1108/07363760610712939 (Accessed: 19 October 2016).

Matten, D. and Crane, A. (2005) 'Corporate Citizenship: Toward an Extended Theoretical Conceptualization', Academy of Management Review, 30(1), pp. 166-179. Available at:

http://www.dirkmatten.com/Papers/Matten/Matten\%26Crane\%20in\%20AMR.pdf (Accessed: 5 December 2016).

www.jbrmr.com A Journal of the Academy of Business and Retail Management (ABRM) 
Mohr, L.A., Webb, D.J. and Harris, K.E. (2001) ‘Do consumers expect companies to be socially responsible? The impact of corporate social responsibility on buying behavior', Journal of Consumer Affairs, 35(1), pp. 45-72. Available at:

http:/ / content.ebscohost.com/ContentServer.asp?T=P\&P=AN\&K=5367621\&S=R\&D=a9h\&EbscoContent=dGJ yMNXb4kSeqLY4wtvhOLCmr06eprBSsq\%2B4SraWxWXS\&ContentCustomer=dGJyMOzprkmvqLJPuePfgeyx 43zx (Accessed: 28 December 2016).

Moisescu, O.I. (2015a) 'Demographics-based differences in the relationship between perceived CSR and customer loyalty in the dairy products market', Management \& Marketing, 10(2), pp. 118-131. Available at:

https://www-degruyter-com.liverpool.idm.oclc.org/downloadpdf/j/mmcks.2015.10.issue-2/mmcks-20150010/mmcks-2015-0010.xml (Accessed: 12 October 2016).

Moisescu, O.I. (2015b) 'The impact of customers' perception of CSR on corporate brand loyalty: The case of the Romanian mobile telecom industry', Central European Business Review, 4(2), pp. 21-30. Available at: http:/ / oaji.net/articles/2015/1215-1436788696.pdf (Accessed: 18 September 2016).

Mulki, J.P. and Jaramillo, F. (2011) 'Ethical reputation and value received: Customer perceptions', International Journal of Bank Marketing, 29(5), pp. 358-372. Available at:

http://www.emeraldinsight.com.liverpool.idm.oclc.org/doi/pdfplus/10.1108/02652321111152891 (Accessed October 2016).

Muwazir, M.R., and Abdul Hadi, N. (2013) 'A Multi-Ethnic Perspective on Corporate Social Responsibility in Malaysia', pp: 1-12. Available at:

http://repository.um.edu.my/27965/1/A\%20multi-ethnic\%20perspective\%20on\%20csr.pdf (Accessed: 25 April 2017).

Nyadzayo, M.W. and Khajehzadeh, S. (2016) 'The antecedents of customer loyalty: A moderated mediation model of customer relationship management quality and brand image', Journal of Retailing and Consumer Services, 30, pp. 262-270. Available at: http://ac.els-cdn.com.liverpool.idm.oclc.org/S096969891630056X/1-s2.0S096969891630056X-main.pdf?_tid=75d31dcc-83fc-11e6-8cda-

00000aacb361\&acdnat=1474903281_f31039ae3b7a8cf106ff7cdb2afd4803 (Accessed: 18 September 2016).

Ooredoo (2016) Annual Report 2016. Available at: http://ooredoo.com/wp-content/uploads/2017/03/OoredooAnnual-Report-2016-EN.pdf (Accessed 18 April 2017).

Oxford Business Group (2017) Qatar's telecoms providers expand operations. Available at:

https://www.oxfordbusinessgroup.com/overview/qatars-telecoms-providers-expand-operations (Accessed: 24 April 2017). Paulík, J., Kombo, F., and Ključnikov, A.(2015) 'CSR as a driver of satisfaction and loyalty in commercial banks in the Czech Republic', Journal of International Studies, Vol. 8, No 3, 2015, pp. $112-127$. Available at: http://www.jois.eu/files/09_Paulik.pdf(Accessed: 14 March 2018).

Pérez, A. and Del Bosque, I.R. (2015) 'An integrative framework to understand how CSR affects customer loyalty through identification, emotions and satisfaction', Journal of Business Ethics, 129(3), pp. 571-584. Available at: http:/ / content.ebscohost.com/ContentServer.asp?T=P\&P=AN\&K=103287590\&S=R\&D=bth\&EbscoContent=d GJyMNLr40SeqK44wtvhOLCmr06eprJSs6\%2B4TLKWxWXS\&ContentCustomer=dGJyMOzprkmvqLJPuePfge yx43zx (Accessed: 20 December 2016).

Pizzutti, C. and Fernandes, D. (2010) 'Effect of recovery efforts on consumer trust and loyalty in e-tail: A contingency model', International Journal of Electronic Commerce, 14(4), pp. 127-160. Available at:

http:/ / content.ebscohost.com/ContentServer.asp?T=P\&P=AN\&K=51893377\&S=R\&D=bth\&EbscoContent=dGJyMM vl7ESep7A4wtvhOLCmr06eprVSsau4TLSWxWXS\&ContentCustomer=dGJyMOzprkmvqLJPuePfgeyx43zx (Accessed: 12 December 2016).

Porter, M.E., and Kramer, M.R. (2006) 'Strategy \& Society: The Link Between Competitive Advantage and Corporate SocialResponsibility', Harvard Business Review. Vol. 84 Issue 12, p78-92. Available at:

http:/ / content.ebscohost.com/ContentServer.asp?T=P\&P=AN\&K=23081414\&S=R\&D=hbs\&EbscoContent=dGJyMN Hr7ESeqa44v\%2BbwOLCmr0\%2BeprJSrqm4TLSWxWXS\&ContentCustomer=dGJyMOzprkmvqLJPuePfgeyx4 3zx (Accessed: 30 April 2017).

Rafiq, M., Fulford, H. and Lu, X. (2013) 'Building customer loyalty in online retailing: The role of relationship quality', Journal of Marketing Management, 29(3-4), pp. 494-517. Available at:

http:/ / content.ebscohost.com/ContentServer.asp?T=P\&P=AN\&K=87341766\&S=R\&D=bth\&EbscoContent=dGJyMM vl7ESep7A4wtvhOLCmr06eprZSrqa4TbGWxWXS\&ContentCustomer=dGJyMOzprkmvqLJPuePfgeyx43zx (Accessed: 12 December 2016).

Rashid, N.R.N.A., Khalid, S.A. and Rahman, N.I.A. (2015) 'Environmental corporate social responsibility (ECSR): Exploring its influence on customer loyalty', Procedia Economics and Finance, 31, pp. 705-713. Available at: http:/ / ac.els-cdn.com/S2212567115011594/1-s2.0-S2212567115011594-main.pdf?_tid=eda762f0-83fb-11e681da-00000aab0f26\&acdnat=1474903052_af8d4385d193b5f1badb5333c97f0af9 (Accessed 19 September 2016). 
Salmones, M. del M.G. de los, Crespo, A.H. and Del Bosque, I.R. (2005) 'Influence of corporate social responsibility on loyalty and valuation of services', Journal of Business Ethics, 61(4), pp. 369-385. Available at: http:/ / content.ebscohost.com/ContentServer.asp?T=P\&P=AN\&K=18813348\&S=R\&D=bth\&EbscoContent=dG JyMMvl7ESeqLQ40dvuOLCmr06ep69Sr6i4TK\%2BWxWXS\&ContentCustomer=dGJyMOzprkmvqLJPuePfgey x43zx (Accessed: 26 September 2016).

Shafei, I. and Tabaa, H. (2016) 'Factors affecting customer loyalty for mobile telecommunication industry', EuroMed Journal of Business, 11(3), pp.347-361. Available at:

http://www.emeraldinsight.com.liverpool.idm.oclc.org/doi/pdfplus/10.1108/EMJB-07-2015-0034 (Accessed: 13 April 2017).

Shin, Y. and Thai, V.V. (2015) 'The impact of corporate social responsibility on customer satisfaction, relationship maintenance and loyalty in the shipping industry', Corporate Social Responsibility and Environmental Management, 22(6), pp. 381-392. Available at:

http:// onlinelibrary.wiley.com.liverpool.idm.oclc.org/store/10.1002/csr.1352/asset/csr1352.pdf? v=1\&t=itk6yts8\&s= a459ead883cbae50c4aa3cf4661a26d036b2ebe3 (Accessed: 19 September 2016).

Simmons, C.J. and Becker-Olsen, K.L. (2006) 'Achieving marketing objectives through social sponsorships', Journal of Marketing, 70(4), pp. 154-169. Available at:

http:/ / content.ebscohost.com/ContentServer.asp?T=P\&P=AN\&K=22285170\&S=R\&D=bth\&EbscoContent=dGJyMM vl7ESeprM4wtvhOLCmr06eprNSrqy4Sq6WxWXS\&ContentCustomer=dGJyMOzprkmvqLJPuePfgeyx43zx (Accessed: 5 December 2016)

Singh, A.S., and Masuku, M.B. (2014) 'Sampling Techniques \& Determination of Sample Size in Applied Statistics Research: an Overview', International Journal of Economics, Commerce and Management, Vol. II, Issue 1, pp:1-22. Available at: http://ijecm.co.uk/wp-content/uploads/2014/11/21131.pdf (Accessed: 10 April 2017).

Singh, J., de los Salmones Sanchez, M. del M.G. and Del Bosque, I.R. (2008) 'Understanding corporate social responsibility and product perceptions in consumer markets: A cross-cultural evaluation', Journal of Business Ethics, 80(3), pp. 597-611. Available at:

http:/ / content.ebscohost.com/ContentServer.asp?T=P\&P=AN\&K=32465934\&S=R\&D=bth\&EbscoContent=dGJyMN Lr40SeqK44wtvhOLCmr06eprBSrqa4S7WWxWXS\&ContentCustomer=dGJyMOzprkmvqLJPuePfgeyx43zx (Accessed: 20 December 2016).

Stanisavljević, M. (2017) 'Does Customer Loyalty Depend on Corporate Social Responsibility?', Naše gospodarstvo/Our Economy, 63(1), 38-46. Available at:

https://www.degruyter.com/downloadpdf/j/ngoe.2017.63.issue-1/ngoe-2017-0004/ngoe-2017-0004.pdf (Accessed: 14 March 2018).

Talpau, A., \&Boscor, D. (2011) 'Customer-Oriented Marketing - A Strategy That Guarantees Success: Starbucks And Mcdonald's', Bulletin of the Transilvania University of Brasov. Series V: Economic Sciences, Available at:

http:/ / content.ebscohost.com/ContentServer.asp?T=P\&P=AN\&K=66180384\&S=R\&D=bth\&EbscoContent=dGJyMN Lr40Sep7E4wtvhOLCmr06eprVSr6a4S7CWxWXS\&ContentCustomer=dGJyMOzprkmvqLJPuePfgeyx43zx (Accessed: 13 December 2016).

Thomaidou, A. and Bellou, V. (2012) 'Customers' Perceptions about Corporate Social Responsibility and the Role of Their Socio-demographic Characteristics', MIBES Transactions, 6(1), pp. 90-99. Available at:

http:/ / mibes.teilar.gr/proceedings/2012/oral/Thomaidou-Bellou.pdf (Accessed: 19 October 2016).

Uncles, M.D., Dowling, G.R. and Hammond, K. (2003) 'Customer loyalty and customer loyalty programs', Journal of Consumer Marketing, 20(4), pp. 294-316. Available at:

http://www.emeraldinsight.com/doi/pdfplus/10.1108/07363760310483676 (Accessed: 14 December 2016).

Vodafone (2016) Vodafone Qatar Annual Report 2015/16. Available at:

http://www.vodafone.qa/files/dmfile/VodafoneQatarAnnualReport2015-2016.pdf(Accessed: 18 April 2017).

Wartick, S.L. and Cochran, P.L. (1985) 'The evolution of the corporate social performance model', Academy of Management Review, 10(4), pp. 758-769. Available at:

http:/ / content.ebscohost.com/ContentServer.asp?T=P\&P=AN\&K=4279099\&S=R\&D=bth\&EbscoContent=dGJ yMMvl7ESeprM4wtvhOLCmr06eprFSsq24TbGWxWXS\&ContentCustomer=dGJyMOzprkmvqLJPuePfgeyx43 zx (Accessed: 5 December 2016).

$\mathrm{Xu}, \mathrm{Y} .(2014)$ 'Understanding CSR from the perspective of Chinese diners: The case of McDonald's', International Journal of Contemporary Hospitality Management, 26(6), pp. 1002-1020. Available at:

http:/ / www.emeraldinsight.com.liverpool.idm.oclc.org/doi/pdfplus/10.1108/IJCHM-01-2013-0051

(Accessed: 26 September 2016). 